\title{
Mandenkan
}

MANDENIKAN Bulletin semestriel d'études linguistiques mandé

$63 \mid 2020$

Numéro 63

\section{On latent nasals in Samogo}

Sur les nasales latentes en samogo

ЛАТЕНТНЫЕ НОСОВЫЕ В САМОГО

\section{Laura McPherson}

\section{(2) OpenEdition}

Journals

Electronic version

URL: https://journals.openedition.org/mandenkan/2314

DOI: 10.4000/mandenkan.2314

ISSN: 2104-371X

\section{Publisher}

Llacan UMR 8135 CNRS/Inalco

\section{Printed version}

Number of pages: $68-88$

ISSN: 0752-5443

\section{Electronic reference}

Laura McPherson, "On latent nasals in Samogo", Mandenkan [Online], 63 | 2020, Online since 21

September 2020, connection on 08 July 2021. URL: http://journals.openedition.org/mandenkan/2314 ; DOI: https://doi.org/10.4000/mandenkan.2314

\section{(c) (i) (2)(2)}

Les contenus de Mandenkan sont mis à disposition selon les termes de la Licence Creative Commons Attribution - Pas d'Utilisation Commerciale - Partage dans les Mêmes Conditions 4.0 International. 


\title{
On latent nasals in Samogo
}

\author{
Laura McPherson \\ Dartmouth College \\ laura.emcpherson@gmail.com
}

\section{Introduction}

The Samogo group of Mande languages straddles the Burkina Faso/Mali border. A branch of Western Mande (Vydrin 2009a; Vydrin 2016), the Samogo group includes Jowulu (AKA Jo, (Carlson 1993; Djilla, Eenkhoorn \& Eenkhoorn-Pilon 2004)), Dzùùngoo (AKA Dzuun, (Solomiac 2007; Solomiac 2014)), Duungoma (AKA Duun, (Hochstetler 1996; Tröbs 2008)), Kpeengo (AKA Kpeen, (Zwernemann 1996)), Bankagooma (AKA Banka), and Seenku (AKA Sambla, Sembla, or Seeku, (Prost 1971; McPherson 2020)). Many of these languages, especially Bankagooma, Kpeengo, and Duungoma, remain severely underdocumented.

A peculiar commonality of the Samogo languages is the presence of what has been described as a floating or latent nasal. At least diachronically a nasal coda, these nasals often trigger alternations on the following consonant reminiscent of consonant mutation in Atlantic languages and beyond (Merrill 2018). In this paper, I provide a comparative look at these nasals, privileging the term "latent", which can encompass both cases of true floating elements as well as the weak or gradient pronunciations of coda nasals in Seenku. In Sections 2-4, I summarize the distribution and realization of latent nasals in Jowulu, Dzùùngoo and Seenku, the three languages with sufficient descriptions of the phenomenon. Section 5 provides a local summary of the Samogo patterns. In Section 6, I look beyond Samogo and situate latent nasals in their broader Mande context. Section 7 concludes and lays out a path for future work.

\section{Jowulu}

Jowulu [ISO 639-3: jow] is spoken by 10,000 people across the Mali/Burkina Faso border, with the majority of villages found on the Malian side. Djilla et al. (2004) 
describe latent nasals as floating, part of a $\mathrm{CV}^{\mathrm{N}}$ syllable structure. In isolation, it is realized as a "weak [i]" after the final vowel. For instance: ${ }^{1}$
(1)a. $/ \mathrm{do}^{\mathrm{N} /}$
[doi]
'partridge'
b. $/ \mathrm{kã} /$
$\left[\mathrm{ka} \tilde{a}^{i}\right]$
'leg'
c. /nkfà̀ $/$
[ykfài]
'day before yesterday'

As the examples in (1) suggest, Jowulu has phonemic nasal vowels in addition to latent nasals. In other words, vowel nasality is independent of floating or latent nasal codas. Table 1 illustrates that each cell of a two by two table for vowel nasality and floating nasals is filled:

Table 1: Independence of vowel nasality and latent nasals in Jowulu

\begin{tabular}{|l|l|l|}
\hline & $/ \mathrm{CV} /$ & $/ \mathrm{CV}^{\mathrm{N}} /$ \\
\hline$/ \mathrm{V} /$ & $t a$ 'go' & $k a^{\mathrm{r}}$ 'here' \\
\hline$/ \tilde{\mathrm{V}} /$ & $t \tilde{a}$ 'build' & $t \tilde{a}^{\mathrm{r}}$ 'squirrel' \\
\hline
\end{tabular}

Before a plosive, the Jowulu latent nasal is realized as a homorganic nasal stop (i.e. it creates an $\mathrm{NC}$ cluster):

(2) a. $/ \mathrm{ko}^{\mathrm{N} /}+/$ bẁ̀ $/$ [kõmbv̀̀] $\quad \rightarrow$ 'man's back'

man back

b. $/$ tấv $/+/$ ta $\quad \rightarrow \quad$ [tấnta $]$ 'squirrel's hole'

squirrel hole

c. $/$ kã̃ $/+/$ kwùù $\rightarrow$ [kãykfừ̀ $]$ 'ankle' leg knot

Example (2a) also shows that the vowel before a nasal is realized as nasal, despite being an oral vowel underlyingly. The authors go on to state that voiceless plosives after nasals are variably voiced, suggesting optional realizations [tấnda] and [kãygvờ̀] for (2b-c) above, though neither of these are explicitly stated in the description.

If the latent nasal precedes a voiced plosive, it will once again be realized as a homorganic nasal. However, the authors state that in this environment, too, we find variation between a homorganic nasal+voiced stop sequence and a single nasal with the place of articulation of the original plosive. These variable outcomes are illustrated in (3) with a labiovelar plosive:

${ }^{1}$ Throughout this paper, I faithfully reproduce the transcriptions given by the original authors, whose conventions especially with regard to tone can differ considerably. Jowulu is a three-tone language, where $\mathrm{L}$ is indicated with a grave accent, $\mathrm{H}$ with an acute accent, and M left unmarked. 
(3)

$$
\begin{aligned}
& / \mathrm{mî́}^{\mathrm{N}} /+/ \mathrm{gb} \dot{\varepsilon} / \quad \rightarrow \quad[\text { mî́ngbć }] \sim[\text { mî́nmé }] \quad \text { 'my arm' } \\
& \text { 1SG arm }
\end{aligned}
$$

Following this same pattern, the authors state that /d/ after a latent nasal can be nasalized to [n]; nevertheless, this nasalization must not be neutralizing, i.e. derived [n] must be phonetically distinct from $/ \mathrm{n} /$, since Jowulu speakers can easily perceive a difference between $/ \mathrm{kõ}^{\mathrm{N}}$-dá $\mathrm{N} /$ 'someone's child', which would vary in pronunciation between [kõndái] and [kõnái], and /koná $/$ 'human being', with only the realization [kõnái]. ${ }^{2}$ In other words, despite the fact that both of these words share a surface pronunciation transcribed as [kõnái], the phonetic detail of the [n] must differ. This question would benefit from deeper phonetic investigation.

Voiced palatals, both the plosive $/ \mathrm{y} /$ and the glide $/ \mathrm{j} /$, are said to exceptionlessly become the palatal nasal $[\mathrm{n}]$ :

(4)a. $/$ jã̃ $/+/$ jà $/ /$ [nãnài] 'chicken's medicine' chicken medicine

b. $/$ kã ${ }^{\mathrm{N}}+/$ jaàl $\rightarrow$ [kãnaà $] \quad$ 'leg ache' leg hurt

Before a voiceless fricative, the latent nasal is realized as nasalization on the preceding vowel and voicing on the following fricative:

(5)a. / jã̃ $/+\quad /$ fó $/ \rightarrow$ [nãvó] 'white chicken'

chicken white

b. $/ \mathrm{ko}^{\mathrm{N} /}+\quad / \int \mathrm{i} / / \quad[$ kõzi] 'take someone' person take

Vowel nasalization is seen clearly in (5b), where the underlying vowel of $/ \mathrm{ko}^{\mathrm{N} /}$ is oral. Note that Jowulu has no phonemic voiced fricatives.

The latent nasal triggers gemination of a following /1/, presumably by assimilating to the $/ 1 /$ :

$$
\begin{aligned}
& / \text { nã̃ } /+/ \text { lú} / \\
& \text { chicken share }
\end{aligned} \rightarrow \text { [nãllú] 'share a chicken' }
$$

The authors offer no examples with a preceding oral vowel to know whether the latent nasal's nasal feature is retained even as it assimilates to the following lateral.

Unlike the lateral, the rhotic/r/ nasalizes to [n] following the latent nasal:

${ }^{2}$ I have reproduced the form $/ \mathrm{kona}^{\mathrm{N}} /$ as the authors transcribe it on p. 104, but in the prose, they suggest that its underlying form is better understood $/ \mathrm{ko}^{\mathrm{N}}+\mathrm{na}^{\mathrm{N}} /(\mathrm{man}+\mathrm{kind})$. In other words, both 'someone's child' and 'human being' can be understood as compound forms. 
$\begin{array}{l}\text { (7) a. } / \mathrm{bu}^{\mathrm{N}} /+/-\mathrm{ru} / \\ \text { canoe in }\end{array} \rightarrow$ [bứnu $] \quad$ 'in the canoe'

b. $/ \mathrm{kã} \mathrm{v} /+/$-rì $\quad \rightarrow \quad[\mathrm{kãnì̀}] \quad$ 'legs'

leg PL

In (7a), we see that the preceding vowel nasalizes due to the following nasal sound. In (7b), we see that the plural vowel also becomes nasal after the nasalization of $/ \mathrm{r} /$ to [n], which is not noted for the locative suffix 'in'. It is unclear whether this is a consistent difference between the two suffixes, or whether it is related to the nasality of the stem vowel (oral in 7a, nasal in 7b).

Interestingly, unlike what we will see in Seenku below, any nasal sound in Jowulu will nasalize $/ \mathrm{r} /$ to [n], including a plain nasal vowel without a latent nasal:

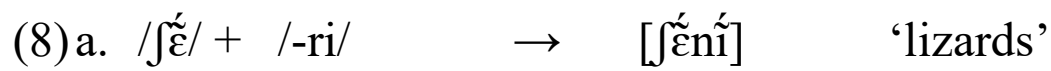

lizard PL

b. /kããa $/+/$-ra/ $\rightarrow$ [kã̃ã́nã $] \quad$ 'farming' farm PROG

Once again, the vowel of the plural suffix nasalizes after [n], as does the vowel of the progressive/participial suffix /-ra/.

Finally, a following nasal consonant will simply absorb the latent nasal:

(9)a. /pév $/+/$ mwõõnã/ $\rightarrow$ [pémwõõnã] 'a lot of horns'

horn a lot

b. /nã $/+/$ nóó/ $\rightarrow$ [nãnóó] 'chicken excrement'

chicken excrement

It is unclear whether the oral vowel ([pém]) in the output of (9a) is a mistake, as we typically see vowel nasalization before a nasal sound in Jowulu.

\section{Dzùùngoo}

Dzùùngoo [ISO 639-3: dnn] is spoken by 13,400 people in southwest Burkina Faso (Solomiac 2007). Like Jowulu, it has a phonemic contrast between oral and nasal vowels that is separate from the presence of a floating nasal. This is demonstrated in Table 2. ${ }^{3}$

${ }^{3}$ Like Jowulu, Dzùùngoo is for the most part a three-tone language (with a rare raised $\mathrm{M}$ as a fourth tone). Solomiac's transcrition conventions differ from those used in Djilla et al. (2004) in that $\mathrm{M}$ tone is marked with a macron (e.g. $\chi \overline{\tilde{\tilde{J}}}$ 'nose'). 
Table 2: Independence of vowel nasality and latent nasals in Dzùùngoo

\begin{tabular}{|l|l|l|}
\hline & $/ \mathrm{CV} /$ & $/ \mathrm{CV} /$ \\
\hline$/ \mathrm{V} /$ & $k \grave{a}$ 'griot' & $k \dot{a}^{\mathrm{N}}$ 'flower' \\
\hline$/ \tilde{\mathrm{V}} /$ & $x \tilde{\tilde{\nu}}$ 'nose' & $k \tilde{a}^{\mathrm{N}}$ 'oppose' \\
\hline
\end{tabular}

(10) a. /kà/ [kà] 'griot'

/káN/ [ká] 'flower'

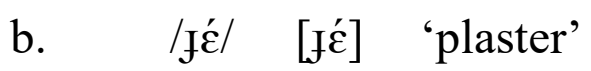

$/ \mathrm{c}^{\mathrm{N}} /[\mathrm{c} \varepsilon \dot{\varepsilon}]$ 'breast'

The presence of the latent nasal is identifiable from the alternations that it triggers on following consonants.

As in Jowulu, the latent nasal is realized as a homorganic nasal stop before plosives: ${ }^{4}$

$/$ dzĩ: ${ }^{N} /+/$ kũggo $/$
child head

Nasal vowels without a latent nasal coda condition the realization of a slight homorganic nasal, but Solomiac (p.c.) notes that this nasal is shorter and weaker and likely a phonetic effect rather than a distinct phonological element:

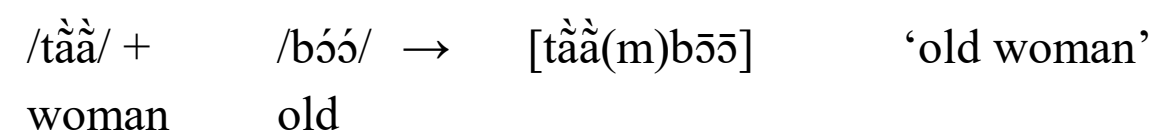

Presumably this environment provides more evidence for floating nasals after oral vowels than it does after nasal vowels. There is no indication that the latent nasal causes voicing of voiceless plosives or nasalization of voiced plosives, as it does in Jowulu.

Similarly, in Dzùùngoo, the latent nasal does not trigger voicing of a following fricative; instead, it is realized as simply nasalization on the preceding vowel:

$/ \mathrm{b} \jmath^{\mathrm{N} /}+/ \mathrm{su} /$
cheek hair $\quad \rightarrow \quad[$ bõsu $] \quad$ 'beard hair'

In this environment, the distinction between nasal vowels and $\mathrm{V}^{\mathrm{N}}$ sequences is likewise neutralized.

The environment that provides the most evidence for the latent nasal in Dzùùngoo is before /r/. Like Jowulu, /r/ becomes [n] after a latent nasal coda, thus distinguishing stems like those in (10) that otherwise both appear with oral vowels in isolation:

${ }^{4}$ Here and in a few other examples below (13, Tables 5-6), tone is not marked in the original examples presented by Solomiac. I have reproduced them as they were given in the original source. 

a. $/$ kàl $+/$-rèè $\quad \rightarrow \quad$ kà-rèè $] \quad$ 'griots'
griot PL

b. $/ \mathrm{ká}^{\mathrm{N}} /+/$-rèè $\rightarrow$ [ká-nèè] 'flowers'

flower PL

Unlike Jowulu, plain nasal vowels do not trigger the nasalization of $/ \mathrm{r} /$ :

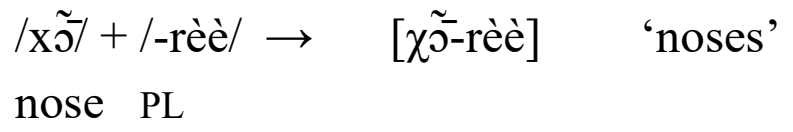

In this way, a latent nasal is distinguishable from phonemic vowel nasalization.

In sum, latent nasal codas in Dzùùngoo can occur on both oral and nasal vowels, but in most environments, its effects cannot be distinguished from one or the other; in isolation, it is not pronounced, and so $/ \mathrm{V}^{\mathrm{N}} /$ is neutralized with $/ \mathrm{V} /$ and $/ \tilde{\mathrm{V}}^{\mathrm{v}} /$ is neutralized with $/ \tilde{\mathrm{V}} /$. Before obstruents, $/ \mathrm{V}^{\mathrm{N}} / \tilde{\mathrm{V}}^{\mathrm{N}} /$ and $/ \tilde{\mathrm{V}} /$ all surface the same, with the exception that the nasal stop from a latent nasal is perceived as stronger than that arising from a simple nasal vowel before a plosive. The most salient effect of the latent nasal is that it triggers a following $/ \mathrm{r} /$ to be realized as [n], which a nasal vowel does not.

\section{Seenku}

Seenku [ISO 639-3: sos] is the easternmost Samogo language, spoken in villages just to the west of the Bobo-Dioulasso metropolitan area in Burkina Faso (McPherson 2020). Also known by its exonym Sambla (French spelling: Sembla), the language has approximately 15,000 speakers. $^{5}$

In light of the Jowulu and Dzùùngoo descriptions of floating nasals, I originally treated Seenku's nasal reflex as floating as well, since it seemed to appear only with a following word and be deleted in isolation. Under such a phonological analysis (employed, for instance, by Solomiac (2007)), the floating nasal must either dock to a following consonant position or a preceding vowel position, rendering those segments phonologically [+nasal], or it is left floating and hence unrealized (e.g. Dzùùngoo /káN/ in isolation pronounced as [ká] 'flower'). However, speakers reported a difference even in isolation between words with a latent nasal and words without. Preliminary phonetic analysis corroborates this intuition, showing that latent nasals are realized in isolation

${ }^{5}$ Tone in Seenku is more complex than in Jowulu or Dzùùnoo, with four contrastive tone levels which I call extra-low (X, ä), low (L, à), high ( $\mathrm{H}$, á) and super-high ( $\mathrm{S}$, ä). These four levels can combine to create numerous contour tones, though most commonly low-superhigh (LS, ă), high-extra-low (HX, â), and super-high-extra-low (SX, ä). Since tone is a property of the syllable rather than each vowel or the mora, I mark tone only once per syllable. Thus, a word like kâa 'fight' represents a long vowel with a HX falling tone, allowing the same diacritic to represent the HX melody on long and short vowels. 
as late nasalization of the vowel. In other words, we find a three-way contrast in isolation between purely oral vowels (e.g. /kâ/ 'griot'), purely nasal vowels (e.g. / kã̃/ 'white'), and late nasalized vowels (e.g. /kâN/ 'granary', realized as [kâãa] ), which indicates that the realization of the nasal is not simply a phonological question of [+nasal] vs. [-nasal] segments, or a docked vs. undocked floating element. The reality is considerably more gradient, and for this reason, I favor the more neutral term "latent" to the phonological term "floating".

Figure 1 shows spectrograms/waveforms from a female speaker for an oral vowel (a), nasal vowel (b), and latent nasal/late nasalized vowel (c).

\section{Figure 1}

Waveform and spectrogram for a) /kâ/ 'griot', b) /kã̃/ 'white', and c) /kâN/ 'granary'

a.
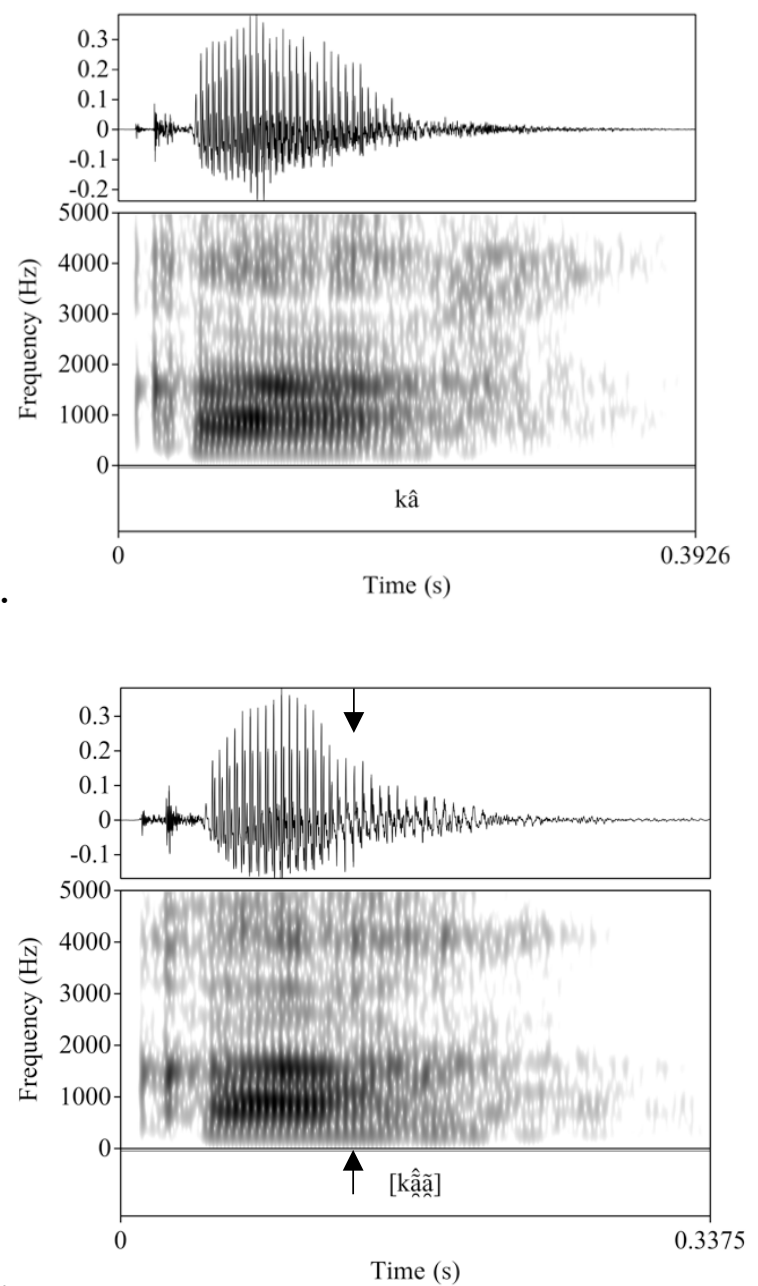

c.

Time (s) b.

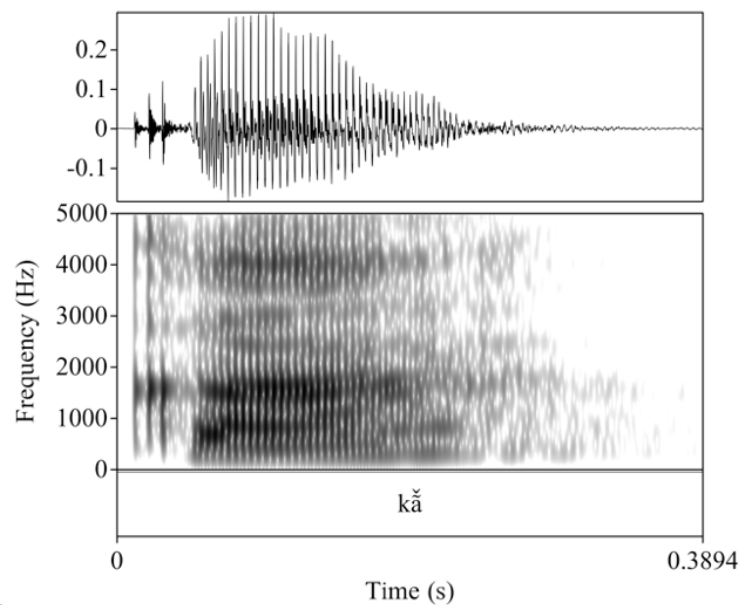

${ }^{6}$ It is difficult to phonetically transcribe late nasalization of a short vowel using the IPA, since a tilde above the vowel would mean full nasalization (and the absence of the tilde would mean an oral vowel). In the transcription system used here, I have appended a short/nonsyllabic vowel [a] to the end of the short vowel, which hosts the nasal tilde. This sequence [aã̃] indicates a short vowel that begins oral and ends nasal. 
In Figure 1a, the vowel formants are clear and smooth throughout the duration of the oral vowel. In Figure 1b, the formant structure is more diffuse in the nasal vowel. Finally, in Figure 1c, we can see a change about halfway through the vowel, indicated with arrows. Before this point, the vowel looks like the oral vowel in Figure 1a; after it, when nasalization begins, the formant structure becomes fuzzy.

The data presented here are meant simply to provide a rough illustration of how the Seenku nasal is realized in isolation. More systematic phonetic study of the nasal will be required to determine with certainty its realization. This includes nasometry to accurately measure oral and nasal airflow, since acoustic measurements of nasality are notoriously challenging. Future work will focus on the collection of these data.

To summarize, because the nasal is still realized even in isolation, just weakly, I choose to refer to it as a "latent" nasal coda rather than a floating nasal. In transcriptions here, I will write it as a large capital N, indicating that place is not contrastive for this nasal coda. It is quite likely that the nasal in Jowulu, at least, has a similar representation, since Djilla et al. (2004) do note that it is subtly realized even in isolation (albeit as a palatal effect, or a "small [i]").

As in the other Samogo languages, latent nasals can co-occur with both oral and nasal vowels in Seenku. This distribution is illustrated in Table 3.

Table 3. Independence of vowel nasality and latent nasals in Seenku

\begin{tabular}{|l|l|l|}
\hline & $/ \mathrm{CV} /$ & $/ \mathrm{CVN} /$ \\
\hline$/ \mathrm{V} /$ & $k \hat{a}$ 'griot' & $k \hat{a} N$ 'granary' \\
\hline$/ \tilde{\mathrm{V}} /$ & $k \tilde{\tilde{a}}$ 'white' & $k \tilde{\tilde{N}} N$ 'head' \\
\hline
\end{tabular}

Before plosives, the latent nasal is realized as a homorganic nasal stop, though as in other languages, it is unclear whether it should be viewed as a coda (grouped with its original stem) or as prenasalization (grouped with the following word): ${ }^{7}$

\begin{tabular}{|c|c|c|c|}
\hline $\begin{array}{l}\text { (16) a. /dôN } /+/ \text { kั̀े/ } \\
\text { child head }\end{array}$ & $\rightarrow$ & [dóìkò̀] & 'child's head' \\
\hline $\begin{array}{l}\text { b. /kâN/ + /bəlě / } \\
\text { granary big }\end{array}$ & $\rightarrow$ & [kâmbəlě] & ‘big granary’ \\
\hline c. /cǔeN/ + /të/ & $\rightarrow$ & [cǔentë] & 'Cuen's' \\
\hline Cuen & & & \\
\hline
\end{tabular}

This nasal does not trigger voicing of voiceless stops nor does it trigger lenition of voiced stops, as we saw in Jowulu.

${ }^{7}$ The tonal alternations found in possession and other environments are beyond the scope of this paper. See McPherson (2019) for further discussion. 
Before fricatives, the latent nasal is realized as nasalization on the preceding vowel, though it varies between full nasalization and late nasalization. For example:

\begin{tabular}{|c|c|c|c|}
\hline $\begin{array}{c}\text { (17) a. / /éN-ıёN/ } \\
\text { story }\end{array}$ & $\begin{array}{l}/ \mathrm{fí} / \\
\text { two }\end{array} \rightarrow$ & 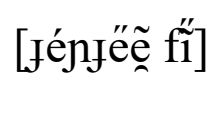 & 'two stories' \\
\hline $\begin{array}{l}\text { b. /sâN/ + } \\
\text { hare }\end{array}$ & $\begin{array}{l}\text { /sio/ } \rightarrow \\
\text { arrive.PRF }\end{array}$ & [sẫ sïo] & 'hare has arrived' \\
\hline
\end{tabular}

Thus, as far as I can tell, the contrast between a latent nasal on an oral vowel and a nasal vowel with or without a latent nasal is optionally neutralized in this environment.

The most interesting behavior of the latent nasal is found before sonorants, namely $/ 1 /$ and $/ \mathrm{w} / .^{8}$ In this environment, $/ \mathrm{l} /$ can be realized as $[\mathrm{n}]$ and $/ \mathrm{w} /$ as $[\mathrm{m}]$ (which I term

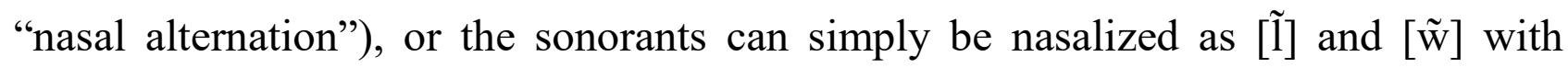
concurrent late nasalization of the preceding vowel (which I term "nasalization"). For example: ${ }^{9}$

\begin{tabular}{|c|c|c|c|}
\hline $\begin{array}{l}\text { 18) a. /dôN/ + /wë/ } \\
\text { child with }\end{array}$ & $\rightarrow$ & [dó mè] [dóồ w ẁ̀ $]$ & 'with a child' \\
\hline b. /säN/ + /lë/ & $\rightarrow$ & 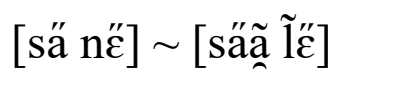 & 'to God' \\
\hline
\end{tabular}

This variation is interesting because while it is free variation (i.e. it could be produced either way with no change in meaning), the rate of nasal alternation vs. nasalization depends on a number of factors, including phrase boundaries, speaker, lexical item, vowel length preceding the nasal, and which sonorant follows. Overall, $/ \mathrm{w} /$ is more likely to undergo nasal alternation than $/ 1 /$. One speaker, GET, is more likely to produce nasal alternation when the latent nasal and sonorant are in the same phonological phrase, such as between a noun and a postposition. Another speaker, SCT, has the opposite pattern, with nasal alternation more likely to cross a phrase boundary, such as between a subject and a predicate. Finally, for both speakers tested, certain lexical items were more likely to trigger nasal alternation than others.

Latent nasals on nouns also interact with plural morphology in interesting ways. Earlier work (McPherson 2017a) distinguished between nouns with floating nasals and

${ }^{8}$ The rhotic [r] is only found in C2 position of sesquisyllabic words like [sərë] 'outside', and $/ \mathrm{j} /$ (orthography $<\mathrm{y}>$ ) is not a native sound in Seenku.

${ }^{9}$ In the phonetic transcription of (18a), we find the form [dó]. This represents a HL falling tone on the short vowel; since the circumflex is already used to indicate the more common HX falling tone, it becomes difficult to transcribe a HL tone pattern using a single diacritic. For this reason, the L tone is left to the right of the syllable, but it should not be understood as a floating tone, merely as a HL tone pattern realized on [o]. 
nouns with true nasal codas, whose behavior differed under plural inflection. "Floating nasals", found mostly on stems with short vowels, are present in the singular, triggering the range of effects described above on the following word. In the plural, however, the nasal appears to be subsumed into the noun stem itself, nasalizing the vowel; this nasal vowel acts like any phonemic nasal vowel and does not interact with the following word. This data pattern is illustrated in (19):
(19) a. kâN
'granary'
c. $\mathrm{k} \ddot{\varepsilon}$
'granaries'
b. kâm bəlě 'big granary'
d. kę bú-bəlě 'big granaries'

As described in McPherson (2017a), the plural suffix in Seenku consists of a floating [+front] vocalic feature and a floating [+raised] tonal feature, which cause vowel fronting and tone raising. They also have the effect of "locking in" the nasality of the latent coda to the stem itself. For more on adjectival morphology in Seenku, see McPherson (2017b).

However, another set of nouns with latent nasal codas, often though not exclusively with long vowels, show a different pattern. As before, the latent nasal in the singular shows the expected range of effects, but it is simply deleted in the plural. For example:
a. böôN
'bag'

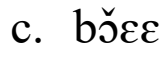
'bags'
b.böôm bəlě 'big bag'
d. bǒec bú-bəlě
'big bags'

Rather than creating *bĎ̨ॄ 'bags' by incorporating the nasal coda into the stem, it is lost completely.

I suspect that rather than a categorical bifurcation of stems into those with floating and those with true codas, the behavior in the plural is likely related to the range of variation of the latent coda in other contexts. For instance, in the case of 'bag', we find that this word is more likely to have its latent nasal realized as a coda even in isolation or before a $/ \mathrm{w} /$, though it can also show the more typical pattern of nasalizing the sonorant to $[\tilde{\mathrm{w}}]$ in this environment.

A formal phonological analysis of the data patterns in Seenku is beyond the scope of this paper, but it will require a stochastic analysis to account for the variation (e.g. maximum entropy harmonic grammar, (Legendre, Miyata \& Smolensky 1990; Hayes \& Wilson 2008)) and possibly a formalism like Gradient Symbolic Representation, e.g. (Smolensky \& Goldrick 2016), which posits that individual segments can have different levels of activation in the lexicon. Under such an account, nasal codas would generally have lower activation than other segments, but lexical items could differ in the activation level of the latent nasal to account for lexical differences in the behavior of latent nasals. 


\section{Local summary}

To summarize what we have seen so far, all documented Samogo languages have a portion of the lexicon with an associated final nasal. This nasal, variably classified as "floating" or "latent", tends to be realized primarily on following sounds or as nasalization on the preceding vowel rather than as a surface nasal coda. In each of the languages, latent nasals are independent of vowel nasalization, which is also phonemically contrastive. ${ }^{10}$

The exact realization of the latent nasal in different environments depends on the language and its phonotactic patterns. The patterns are summarized in Table 4.

Table 4: Summary of the realization of the latent nasal

\begin{tabular}{|c|l|l|l|}
\hline & Jowulu & Dzùùngoo & Seenku \\
\hline $\begin{array}{c}\text { Isolation } \\
\text { Plosive } \\
{[- \text { voice }]}\end{array}$ & $\begin{array}{l}\text { Light }[\mathrm{i}] \\
\text { vomorganic nasal }+\end{array}$ & Deleted & Homorganic nasal \\
\hline $\begin{array}{c}\text { Plosive } \\
{[+ \text { voice }]}\end{array}$ & $\begin{array}{l}\text { Homorganic nasal }+ \\
\text { nasalization of } \\
\text { plosive }\end{array}$ & Homorganic nasal & Homorganic nasal \\
\hline Fricative & $\begin{array}{l}\text { Nasalization of vowel } \\
\text { and voicing of } \\
\text { fricative }\end{array}$ & $\begin{array}{l}\text { Nasalization of } \\
\text { vowel }\end{array}$ & $\begin{array}{l}\text { Homorganic nasal } \\
\text { of vowel }\end{array}$ \\
\hline Nasal & Deletion/absorption & Deletion/absorption & Deletion/absorption \\
\hline$/ \mathrm{r} /$ & $/ \mathrm{r} / \rightarrow[\mathrm{n}]$ & $/ \mathrm{r} / \rightarrow[\mathrm{n}]$ & $\mathrm{N} / \mathrm{A}$ \\
\hline$/ \mathrm{l} /$ & Gemination of $/ \mathrm{l} /$ & $?$ & $/ \mathrm{l} / \rightarrow[\tilde{1}] \sim[\mathrm{n}]$ \\
\hline$/ \mathrm{w} /$ & $?$ & $?$ & $/ \mathrm{w} / \rightarrow[\tilde{\mathrm{w}}] \sim[\mathrm{m}]$ \\
\hline
\end{tabular}

While data on some environments is missing, we see that Dzùùngoo and Seenku are the most similar, while Jowulu tends towards greater effects on the following consonant, especially in terms of voicing, which is typologically natural after a nasal (cf. *NCo, (Pater 1999)). Given these facts, it comes as little surprise that Jowulu has seen more treatment under the heading of "consonant mutation" patterns, e.g. (Merrill 2018).

${ }^{10}$ There is one possible exception to this independence, namely that in Dzùùngoo and Seenku, nasalized high vowels are uniformly followed by a latent nasal. It may be that the greater acoustic coupling of low F1 in high vowels and the nasal formant reduces the perceptibility of nasality on these vowels, and the latent nasal thus serves to reinforce this nasality. 
Lexical comparison of the three Samogo languages reveals that, in many cases, the latent nasal is stable across cognates. Note that Jowulu and Seenku are overrepresented in the following table, since Dzùùngoo orthography conflates nasal codas and nasal vowels, thus meaning that the only stems with identifiable latent nasals are those that are explicitly discussed as such. Table 5 provides some examples of (potential) cognates with coda nasals, transcribed here as $\mathrm{N}$ for consistency.

Table 5: Samogo cognates with consistent latent nasals

\begin{tabular}{|c|c|c|c|}
\hline Jowulu & Dzùùngoo & Seenku & Gloss \\
\hline dáN & dzĩ́n & dóN & 'child' \\
\hline féN & & $\mathrm{p} \varepsilon \ddot{N}$ & 'wooden cane for tamping floors' \\
\hline \multirow[t]{3}{*}{ kãN } & & $c \ddot{\tilde{\varepsilon}} \mathrm{N}$ & 'foot/leg' \\
\hline & káN & káN & 'flower' \\
\hline & $\mathrm{soN}$ & sóN & 'heart' \\
\hline péN & & bî́N & 'horn' \\
\hline tẽN & & sóeN & 'one' \\
\hline fîN & & $f \hat{\varepsilon} \mathrm{N}$ & 'thing' \\
\hline dziN & & döN & 'today' \\
\hline nế $\mathrm{N}$ & cé $\mathrm{N}$ & 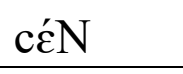 & 'breast' \\
\hline $\mathrm{fiN}$ & & fôN & 'fonio' \\
\hline
\end{tabular}

Nevertheless, we also find a few cases where languages diverge, suggesting some instability or uncertainty in the patterns that can lead learners to either reinterpret codas as vowel nasality or lose them altogether. These cases are shown in Table 6.

Table 6: Samogo cognates with inconsistent latent nasals

\begin{tabular}{|l|l|l|l|}
\hline Jowulu & Dzùùngoo & Seenku & Gloss \\
\hline tfũN & & tsü & 'straw/thatch' \\
\hline & tsy文 & cëN & 'peanut' \\
\hline & baaN & bẫã & 'balafon' \\
\hline
\end{tabular}

The two pairs from Dzùùngoo and Seenku show that reinterpretation occurs in both directions: A Dzùùngoo nasal vowel can correspond to a Seenku coda and vice versa. As these two tables suggest, latent nasals are more often consistent than not across the three languages.

Further documentation of other Samogo languages will allow us to compare these patterns more broadly within the group and trace a diachronic path for the changes. 


\section{Beyond Samogo}

When we look beyond the Samogo languages to broader Mande, we find far greater diversity in terms of nasal patterns. In typologizing Mande nasality, we can define the following parameters of variation:

1. Presence of phonemic nasal vowels.

2. Presence of phonemic nasal consonants.

3. Presence of nasal codas.

4. Effect of nasality on following consonants.

Of course, these parameters are not independent, and in fact, it appears that they can sometimes be a matter of analysis.

First, we can consider Parameter 1, the presence of phonemic nasal vowels. These are unequivocally attested in Samogo, as they are South Mande (Vydrine 2004; Vydrine 2005a) and other (South-)Western Mande languages like Bobo (Boone 2016), Kpelle (Welmers 1962), and Jalkunan (Heath 2017). However, many Manding-Mokole languages are analyzed with only oral vowels underlyingly. This includes Guinean Maninka (Diané \& Vydrin 2014), Niokolo Maninka (Creissels 2013), Lele (Vydrin 2009b), and Kakabé (Vydrina 2015); vowel nasalization, where present, is analyzed as the result of a nasal coda (Parameter 3). Nevertheless, other major Manding languages like Bambara, e.g. (Green 2010) or Jula, e.g. (Donaldson 2013) are analyzed as having a phonemic oral/nasal vowel contrast but no nasal codas. While I am not certain of the exact phonetic and phonological criteria used by every author to decide the source of vowel nasalization, it seems plausible that the opposite analysis would be possible for at least some languages, since nasal codas and vowel nasalization are not contrastive in these languages. For a discussion of the development of nasal vowels and/or codas (discussed as prenasalized consonants) in Central Mande, see Kastenholz (1989).

The same general pattern seems to hold in Soninke-Bozo as we see in Manding, namely that surface nasal vowels can be analyzed as the result of nasal codas; for Kingi Soninke, see (Creissels 2016); for Bozo-Jenaama, see (Lauschitzky 2007). It is unclear whether nasality in these languages could be fruitfully reanalyzed as vocalic rather than consonantal.

Just as we can ask whether nasality is a contrastive feature on vowels, we can also ask whether it is contrastive for consonants (Parameter 2). For most of Western Mande, including Manding, the answer appears to be "yes"; in many South Mande languages, however, nasality behaves suprasegmentally as a property of the foot, encompassing both vowels and consonants (Vydrine 2004; Vydrine 2005b). Under this analysis, nasal consonants are the result of spreading a vowel's [nasal] feature to the rest of the foot. For example, in Mwan (Perekhvalskaya \& Yegbé 2018), /6/ and /d/ in a nasal foot will be realized as $[\mathrm{m}]$ and $[\mathrm{n}]$. Thus, nasality is still a phonemic feature of the language 
(see e.g. Kono, (Konoshenko 2017); Mano, (Khachaturyan 2018)), but not for consonantal phonemes.

Parameter 3 asks whether the language has nasal codas, either instead of or in addition to nasal vowels and consonants. As mentioned above, nasality in many Manding languages and the Soninke-Bozo group is analyzed as resulting from a nasal coda, which is the only source of vocalic nasality in the language. Many other languages pattern like Samogo, with vowel nasality an independent parameter from the presence of a nasal coda. Bobo Madaré South, for instance, contrasts oral and nasal vowels, and both may co-occur with a coda / $\mathrm{y} /$ (Boone 2016). The same situation holds for Kpelle (Welmers 1962) and many of the South Mande languages, where the $/ \mathrm{y} /$ is sometimes analyzed as a vowel, e.g. (Khachaturyan 2015), since it acts as a tone bearing unit. Jalkunan (Heath 2017) appears to have coda nasals on the surface, though seemingly due to an apocope process rather than arising from an underlying coda.

This brings us to Parameter 4, the effects of nasality on following consonants. Languages differ both in how extensive alternations are (i.e. affecting only very specific sounds or a broader set of sounds) and in the range of possible triggers (i.e. nasal vowels, nasal codas, or both). In Samogo, as we saw in this paper, it is typically only the latent nasal coda that has any effect on following consonants, while phonemic nasal vowels are inert; the range of alternations that they trigger, though, can be extensive.

Grégoire (1987) shows that consonant alternations of the Samogo sort are relatively widespread in Mande. The closest parallel in terms of triggers and effects can be found in South Mande, also described by Vydrine (2004). As in Samogo, nasal codas (and/or syllabic nasals) in South Mande can trigger assimilation on the following consonant in terms of voicing and/or nasality. In Mano (Khachaturyan 2018), for instance, syllabic and coda nasal $/ \mathfrak{y} /$ assimilates in place of articulation to the following consonant, which undergoes voicing and nasalization, resulting in geminate nasals (e.g. $/ \mathrm{y} 6 / \rightarrow[\mathrm{mm}])$. Like the Samogo languages, we see variation between dialects of Mano in the nasal alternations. In one dialect, only the implosive and sonorants undergo nasalization, while in the Maa dialect, other consonants do as well, including voiceless fricatives (e.g. /ys/ $\rightarrow$ [nn]). Perhaps like Jowulu's isolation pronunciation [i], the coda nasal [y] is realized as a "closed nasal vowel" in final position (Khachaturyan 2015). A similar situation holds in Beng (Paperno 2014), but with only a singleton nasal as the result (e.g. $/ \mathrm{nd} / \rightarrow[\mathrm{n}]$ ) and many phonological and morphosyntactic restrictions on the process; for instance, it applies generally with sonorants within a compound word but only sporadically with initial obstruents, and then only triggered by the $1 \mathrm{SG}$ pronoun in high frequency constructions. 
Even in languages that are not typically considered to have consonant alternations, we find small pockets of similar phenomena. For instance, many of the Manding languages see the nasalization of $/ 1 /$ to [n] after a nasal vowel or a nasal coda, depending upon how nasality is analyzed in the language. In a unique parallel with Jowulu, the syllabic nasal or nasal coda in Niokolo Maninka will denasalize and assimilate to a following /1/, creating a geminate (Creissels 2013).

By far the most extensively documented consonant alternations in Mande, related either synchronically or diachronically to nasals, can be found in the Southwestern Mande languages, such as Kpelle, Mende, Looma, or Kono. For instance, Dwyer (1974) shows that in the Southwestern Mande languages, morpheme-final nasals are (or were) responsible for alternations between "weak" and "strong" realization of consonants. The effects of the nasal can differ by language; in Bandi, the presence of a nasal causes a voiceless onset to remain voiceless as the nasal assimilates to it (while intervocalic voiceless consonants weaken), whereas in Kpelle, the nasal causes the voiceless consonant to become voiced - more similar to what we see elsewhere in Mande. It should be noted that some Southwestern Mande languages, especially Mende, have evolved such that consonant mutation can no longer be linked synchronically to nasals, instead being triggered by morphosyntactic environment, see e.g. (Conteh, Cowper \& Rice 1986; Iosad 2008).

To summarize, while diverse patterns are attested across Mande with respect to nasality, we also find many similarities. Nasal codas, whether separate from vowel nasality or not, tend to be realized homorganically with plosives and to nasalize /1/ to [n] (with rare exceptions). A subset of languages, especially in the South and Southwest Mande groups, show further effects on following consonants, though interestingly these extreme effects tend to be found only in languages with both phonemic vowel nasality and coda nasals. Languages analyzed with only nasal vowels, like Bambara and Jula, still show homorganic nasal stop insertion before plosives and nasalization of /1/ to [n], which raises questions about whether their phonological representations of nasality really differ greatly from those found in languages like Manding or Kakabé, analyzed with only nasal codas.

Finally, echoing Vydrine (2004), we find striking similarity in the systems of nasality in the South Mande languages and Samogo, with both groups showing independent vowel nasality and nasal codas. This is not the only phonological similarity between these groups of languages; both tend towards monosyllabicity, have complex tone systems ( $3+$ levels of tone), larger vowel inventories (monophthongs and diphthongs), etc. From a genealogical point of view, there is no reason why the Samogo group in particular should show so many similarities to South Mande, while other Western Mande languages do not. Could there have been a period of sustained contact? 
Or could the evolutionary pressures that led to word compression (resulting, among other things, in more robust tonal systems) have arisen independently in each group? I leave this question for future research.

For a cross-linguistic survey of nasal vowel inventories, including Mande languages, see Rolle (2013).

\section{Conclusions}

In this paper, I have provided an overview of the phenomenon of latent or floating nasal codas in the Samogo languages for which extensive phonological description is available. Drawing on phonetic data from Seenku, I question the designation of "floating", suggesting instead that these nasal codas are simply weak elements; as such, they may be well suited to recent developments in phonological theory like Gradient Symbolic Representation (Smolensky \& Goldrick 2016), but with the effects of gradience still felt at the surface level and not simply at an underlying one.

A survey of nasality patterns in other Mande languages revealed many variations on a theme; in many languages, vowel nasality and nasal codas are one and the same, while in the South Mande languages and Bobo, they tend to be contrastive, as in Samogo. Regardless of contrast, the realizations of nasality in contact with a following consonant are highly similar across languages.

It is worth speculating on how such a situation, especially with contrastive nasalization and nasal codas, could have arisen. The diachronic path from nasal codas to nasal vowels is well known (for Romance languages, see (Sampson 1999); for Bantu, see (Hombert 1986)), though nasalization can also arise from a preceding nasal consonant (see also (Vydrine 2004)). This same relationship between nasal codas and nasal vowels can arguably be seen in those languages where a nasal coda is the source of vowel nasalization synchronically. On the flip side, nasal codas have also been shown to emerge from nasal vowels, e.g. (Shosted 2006); this could explain the development of nasal codas in a language without a contrast between nasal vowels and codas, but would fail to explain the presence of nasal codas after oral vowels in the Samogo or South Mande languages.

If original nasal codas were presumed to be the source of nasal vowels in Mande more broadly (Vydrin (Vydrine 2005a) posits that they are reconstructable back to Proto-Mande), then there must have been multiple rounds of reduction and coalescence to yield new nasal codas on both oral and nasal vowels in Samogo and South Mande; given the short word length in both of these groups, such a diachronic development seems plausible. What is interesting is that these new nasal codas tend to exert a greater influence on following words than on the preceding vowel. In some languages like Jowulu, nasal codas are evolving towards a system of initial consonant mutation, which could at some point be reanalyzed by learners as morphosyntactically or prosodically 
triggered (à la Mende, (Dwyer 1969; Iosad 2008)), in which case the nasal codas would again be lost.

Future work on Mande nasal codas should look to incorporate more phonetic evidence, including articulatory or airflow studies to determine the extent to which codas truly remain in isolation or the timing of the nasal gesture with respect to preceding vowels or following consonants. Taken together with phonological patterns, this may help tease apart questions of representation (is the coda floating or latent?) and could provide evidence for how different patterns of nasality have evolved and continue to evolve in Mande languages.

\section{References}

Boone, Cornelia. 2016. Tone in the Bobo Madare North noun system. Leiden: Leiden university Masters thesis.

Carlson, Robert. 1993. A sketch of Jo: A Mande language with a feminine pronoun. Mandenkan 25. 1-109.

Conteh, Patrick, Elizabeth Cowper \& Keren Rice. 1986. The environment for consonant mutation in Mende. In Gerrit J. Dimmendaal (ed.), Current Approaches to African Linguistics, 107-116. Foris. Dordrecht.

Creissels, Denis. 2013. Le maninka du Niokolo (Sénégal oriental), esquisse phonologique et morphosyntaxique, liste lexicale, textes glosés. Mandenkan 49. 1218.

Creissels, Denis. 2016. Phonologie segmentale et tonale du soninké (parler du Kingi). Mandenkan 55. 3-174.

Diané, Mamadi \& Valentin Vydrin. 2014. Propositions pour l'orthographe du maninka (Guinée). Mandenkan 52. 3-21. https://doi.org/10.4000/mandenkan.301.

Djilla, Mama, Bart Eenkhoorn \& Jacqueline Eenkhoorn-Pilon. 2004. Phonologie $d u$ jôwulu ("samogho”) (Mande Languages and Linguistics 6). Köln: Rüdiger Köppe Verlag.

Donaldson, Coleman. 2013. Jula Ajami in Burkina Faso: A grassroots literacy in the former Kong empire. Working Papers in Educational Linguistics 28(2). 19-36.

Dwyer, David J. 1969. Consonant mutation in Mende. East Lansing: Michigan State University M.A.Thesis.

Dwyer, David J. 1974. The historical development of Southwestern Mande consonants. Studies in African Linguistics 5(1). 59-94.

Green, Christopher R. 2010. Prosodic phonology in Bamana (Bambara): Syllable complexity, metrical structure, and tone. Doctoral dissertation. Bloomington: Indiana University $\mathrm{PhD}$ dissertation. 
Grégoire, Claire. 1987. Quelques hypothèses concernant l'alternance consonantique initiale dans les langues mandé. Mandenkan 14-15. 171-191.

Hayes, Bruce \& Colin Wilson. 2008. A maximum entropy model of phonotactics and phonotactic learning. Linguistic Inquiry 39. 379-440.

Heath, Jefferey. 2017. A grammar of Jalkunan (Mande, Burkina Faso). https://deepblue.lib.umich.edu/handle/2027.42/139025 (10 September, 2019).

Hochstetler, Lee. 1996. Enquête linguistique sur le duungoma: une langue samogo parlée au Burkina Faso et au Mali. Mandenkan 31. 1-57.

Hombert, Jean-Marie. 1986. The development of nasalized vowels in the Teke language group (Bantu). In Koen Bogers, Harry van der Hulst \& Marten Mous (eds.), The phonological representation of suprasegmentals: Studies on African languages offered to John M. Stewart on his 60th birthday (Publications in African Languages and Linguistics 4), 359-379. De Gruyter Mouton.

Iosad, Pavel. 2008. Initial consonant mutation and information flow in Mende. In Old World Conference in Phonology 5.

Kastenholz, Raimund. 1989. Voyelles nasales et consonnes prénasalisées en position médiane dans les langues mande centrales. Mandenkan 18. 43-60.

Khachaturyan, Maria. 2015. Grammaire du mano. Mandenkan 54. 1-252.

Khachaturyan, Maria. 2018. A sketch of dialectal variation in Mano. Mandenkan 59. 31-56. https://doi.org/DOI: 10.4000/mandenkan.1308.

Konoshenko, Maria. 2017. Field notes on Kono, a Southwestern Mande lect of Forest Guinea. Mandenkan 57. 77-107. https://doi.org/10.4000/mandenkan.1092.

Lauschitzky, Christiane. 2007. The verb in Bozo-Jenaama. Leiden: Leiden university M.A.Thesis.

Legendre, Géraldine, Yoshiro Miyata \& Paul Smolensky. 1990. Harmonic Grammar: A formal multi-level connectionist theory of well-formedness: Theoretical foundations. In Proceedings of the twelfth annual conference of the Cognitive Science Society, 884-891. Cambridge, MA: Erlbaum.

McPherson, Laura. 2017a. Multiple feature affixation in Seenku plural formation. Morphology 27(2). 217-252.

McPherson, Laura. 2017b. The morphosyntax of adjectives in Seenku [sos]. Mandenkan 57. 25-48. https://doi.org/10.4000/mandenkan.1041.

McPherson, Laura. 2019. Seenku argument-head tone sandhi: Allomorph selection in a cyclic grammar. Glossa 4.1(22). https://doi.org/10.5334/gjgl.798.

McPherson, Laura. 2020. A Grammar of Seenku (Mouton Grammar Library 83). Berlin: De Gruyter - Mouton.

Merrill, John. 2018. The historical origin of consonant mutation in the Atlantic languages. UC Berkeley PhD dissertation. 
Paperno, Denis. 2014. Grammatical sketch of Beng. Mandenkan 51. 1-130.

Pater, Joe. 1999. Austronesian nasal substitution and other NC effects. In René Kager (ed.), The prosody-morphology interface, 310-343. Cambridge: Cambridge University Press.

Perekhvalskaya, Elena \& Moïse Yegbé. 2018. Dictionnaire mwan-français. Mandenkan 60. 3-122.

Prost, André. 1971. Eléments de sembla: phonologie, grammaire, lexique (Haute Volta: groupe mandé) (Afrique et Langage, Documents 5). Lyon.

Rolle, Nicholas. 2013. Nasal vowel patterns in West Africa. UC Berkeley PhonLab Annual Report 9(9). 226-267.

Sampson, Rodney. 1999. Nasal vowel evolution in Romance. Oxford University Press. Shosted, Ryan. 2006. Vocalic context as a condition for nasal coda emergence: aerodynamic evidence. Journal of the International Phonetic Association 36(1). $39-58$.

Smolensky, Paul \& Matthew Goldrick. 2016. Gradient symbolic representations in grammar: The case of French liaison. Rutgers Optimality Archive 1286.

Solomiac, Paul. 2007. Phonologie et morphosyntaxe du dzùùngoo de Samogohiri. Lyon: Université Lumière Lyon $2 \mathrm{PhD}$ dissertation.

Solomiac, Paul. 2014. Phonologie et morphosyntaxe du dzùùngoo de Samogohiri (Mande Languages and Linguistics / Langues et Linguistique Mandé 10). Köln: Rüdiger Köppe Verlag.

Tröbs, Holger. 2008. Duun. In Holger Tröbs, Eva Rothmaler \& Kerstin Winkelmann (eds.), La qualification dans les langues africaines. Qualification in African Languages, 71-86. Köln: Rüdiger Köppe.

Vydrin, Valentin. 2009a. On the problem of the Proto-Mande homeland. Journal of language relationship 1. 107-142.

Vydrin, Valentin. 2009b. Esquisse de la langue lélé (groupe mokolé). Mandenkan 45. 29-104.

Vydrin, Valentin. 2016. Toward a Proto-Mande reconstruction and an etymological dictionary. Faits de Langues 47. 109-123.

Vydrina, Alexandra. 2015. Dictionnaire de la langue kakabé suivi d'un index françaiskakabé. 53. 1-253. https://doi.org/10.4000/mandenkan.376.

Vydrine, Valentin. 2004. Areal and genetic features in West Mande and South Mande phonology: In what sense did Mande languages evolve? Journal of West African Languages 30(2). 113-125.

Vydrine, Valentin. 2005a. Quelques recommendations méthodologiques concernant la description des langues mandé-sud. Mandenkan 41. 1-22. 
Vydrine, Valentin. 2005b. Reconstruction of initial consonants in Proto-South-Mande. In Koen Bostoen \& Jacky Maniacky (eds.), Studies in African comparative linguistics, 43-88. Tervuren: Royal Museum for Central Africa.

Welmers, William E. 1962. The phonology of Kpelle. Journal of African Languages 1(1). $73-101$.

Zwernemann, Jürgen. 1996. Documents kpeego. Cahiers Voltaïques / Gur Papers 1. $147-164$.

\section{Laura McPherson}

\section{On latent nasals in Samogo}

Languages in the Samogo group display a phenomenon referred to as "floating" or "latent" nasals. Though belonging to the end of a word (either synchronically or diachronically) in coda position, latent nasals more often appear as mutations or modifications to either the initial consonant of the following morpheme or the preceding vowel. This paper draws together extant descriptive data on Samogo nasals and considers them in the broader typology of consonant and vowel nasality in Mande. Finally, the question of phonological representation vs. phonetic realization is considered with preliminary acoustic data from Seenku [sos]; the weak surface realization of the nasal raises questions about an analysis in which it is floating and suggests that recent developments in Gradient Symbolic Representation (Smolensky \& Goldrick 2016) may be applicable to the data.

Keywords: Samogo, nasal, coda, phonetics, phonology

\section{Laura McPherson}

\section{Sur les nasales latentes en samogo}

Les langues du groupe samogo montrent un phénomène que l'on peut appeler des nasales "flottantes" ou "latentes". Bien que ces nasales fassent partie du coda d'un mot (soit synchroniquement, soit diachroniquement), elles apparaissent le plus souvent comme des mutations ou modifications de la consonne initiale du morphème suivant ou de la voyelle précédente. Cet article rassemble les données descriptives existantes sur les nasales samogo et les examine dans le contexte typologique de la nasalité vocalique et consonantique en mandé. Enfin, je considère la question de la représentation phonologique par rapport à la réalisation phonétique avec des données acoustiques préliminaires en seenku [sos]; la réalisation faible du nasale remet en question une analyse où elle est "flottante" et suggère plutôt que des développements récents dans le cadre de la théorie Gradient Symbolic Representation (Smolensky \& Goldrick 2016) peuvent être utiles pour ces données.

Mots clé : Samogo, nasale, coda, la phonétique, phonologie 
Лаура МакФерсон

\section{Латентные носовые в самого}

Языки группы самого демонстрируют явление, которое обычно называют «плавающими» или «латентными» носовыми элементами. Эти элементы локализуются в конце слова (и в синхронном, и в диахроническом отношении), но проявляются чаще всего в изменениях или чередованиях начальных согласных последующих морфем или предшествующих гласных. В статье сводятся воедино доступные данные о носовых в языках самого, и эти данные рассматриваются в контексте более широкой типологии консонантной и вокалической назальности в семье манде. Вопрос о фонологическом представлении в отношении к фонетической реализации рассматривается применительно к предварительным акустическоим данным языка сенко [sos]: слабая поверхностная назализация носового ставит вопрос о возможности интерпретации его как плавающего, выдвигается предположение о том, что к этим данным может быть пременена методика Gradient Symbolic Representation (Smolensky \& Goldrick 2016).

Ключевые слова: самого, носовые, кода, фонетика, фонология 